Journal of Tropical Ecology

http://journals.cambridge.org/TRO

Additional services for Journal of Tropical Ecology:

Email alerts: $\underline{\text { Click here }}$

Subscriptions: $\underline{\text { Click here }}$

Commercial reprints: $\underline{\text { Click here }}$

Terms of use : $\underline{\text { Click here }}$

\title{
Frugivorous bats drink nutrient- and clay-enriched water in the Amazon rain forest: support for a dual function of mineral-lick visits
}

Simon J. Ghanem, Hans Ruppert, Thomas H. Kunz and Christian C. Voigt

Journal of Tropical Ecology / Volume 29 / Issue 01 / January 2013, pp 1 - 10

DOI: 10.1017/S0266467412000740, Published online: 21 January 2013

Link to this article: http://journals.cambridge.org/abstract_S0266467412000740

How to cite this article:

Simon J. Ghanem, Hans Ruppert, Thomas H. Kunz and Christian C. Voigt (2013). Frugivorous bats drink nutrient- and clayenriched water in the Amazon rain forest: support for a dual function of mineral-lick visits. Journal of Tropical Ecology, 29, pp 1-10 doi:10.1017/S0266467412000740

Request Permissions : $\underline{\text { Click here }}$ 


\title{
Frugivorous bats drink nutrient- and clay-enriched water in the Amazon rain forest: support for a dual function of mineral-lick visits
}

\author{
Simon J. Ghanem*, ${ }^{*}, 1$, Hans Ruppert $\dagger$, Thomas H. Kunz $\ddagger$ and Christian C. Voigt*,§ \\ * Leibniz Institute for Zoo and Wildlife Research, Evolutionary Ecology Research Group, Alfred-Kowalke-Str. 17, 10315 Berlin, Germany \\ $\dagger$ Geosciences Center, Department of Sedimentology and Environmental Geosciences, University of Göttingen, Goldschmidtstr. 3, 37077 Göttingen, Germany \\ $\ddagger$ Center for Ecology and Conservation Biology, Department of Biology, Boston University, 5 Cummington Str., 02115 Boston, USA \\ $\S$ Freie Universität Berlin, Verhaltensbiologie, Takustr. 6, Berlin, Germany \\ (Received 4 May 2012; revised 17 December 2012; accepted 18 December 2012; first published online 21 January 2013)
}

\begin{abstract}
In Central Amazonia, large mammals create water-filled puddles when consuming soil. These mineral licks are visited by pregnant and lactating frugivorous bats; possibly for two reasons. Frugivorous bats could supplement their mineral-depleted fruit diet by drinking salty water, or they could buffer dietary plant secondary compounds by consuming soil. We analysed bat fruits from Ecuador and showed that they are depleted in elemental concentrations (Na, K, P) compared with similar fruits collected from Costa Rica, where no mineral licks occur $(\mathrm{n}=32)$. Analyses of water from Ecuador revealed that water samples from six mineral licks contained more physiologically relevant elements (Na, K, Mg, Ca) than four samples from river and stream water control sites (Mann-Whitney U-test). In support of the nutrient supplement hypothesis, we observed bats drinking mineral-enriched water at these licks (video observation). Furthermore, blood collected from 68 bats differed in composition with respect to physiologically relevant minerals ( $\mathrm{Na}, \mathrm{K}, \mathrm{Mg}, \mathrm{Fe}$ ) from that of frugivorous bats captured at control sites. To test whether frugivorous bats also consumed clay for detoxification, we checked for soil tracer elements in 31 faecal samples. Soil tracers are insoluble in water and, thus, are not included in a strict fruit diet. Bats from mineral licks showed higher aluminium soil tracer concentrations in their faeces than bat species that never visit licks, suggesting that frugivorous bats take up clay material at mineral licks. Our results provide evidence that frugivorous bats ingest soluble mineral nutrients and insoluble soil by consuming soil-enriched water at mineral licks, thus supporting the hypothesis that frugivorous bats of western Amazonia may derive a dual benefit from drinking water from mineral licks.
\end{abstract}

Key Words: detoxification, geophagy, nutrient supplementation, secondary metabolites, soil tracer

\section{INTRODUCTION}

Over recent decades, consumption of soil, called geophagy, has been described for various frugivorous and omnivorous animals. Among vertebrates, examples for this widespread behaviour can be found in birds (Brightsmith \& Muñoz-Najar 2004, Diamond et al. 1999, Gilardi et al. 1999) and many mammals (Blake et al. 2010, Kreulen 1985, Montenegro 2004). Several explanations for geophagy have been suggested (reviewed in Diamond 1999, Klaus \& Schmid 1998) and usually at least some medicinal benefit has been associated with the consumption of soil (Krishnamani \& Mahaney 2000). However, the most common explanation for geophagy has been associated with nutrient supplementation or

\footnotetext{
${ }^{1}$ Corresponding author. Email: sghanem@gmx.de
}

detoxification of plant secondary compounds (Abrahams \& Parsons 1996, Holdø et al. 2002, Mahaney \& Krishnamani 2003, Voigt et al. 2008). The nutrientsupplementation hypothesis assumes that animals ingest clay material for its nutrient content (Brightsmith \& Muñoz-Najar 2004, Emmons \& Stark 1979, Kreulen 1985). The detoxification hypothesis argues that ingested clay may help in buffering toxic, carcinogenic, teratogenic or nutrient-binding effects of plant secondary compounds, such as tannins or alkaloids (Brightsmith et al. 2008, Diamond 1999, Gilardi et al. 1999).

In western Amazonia, frugivorous and omnivorous bats visit muddy depressions in forested areas for geophagy (Bravo et al. 2008, 2010; Tuttle 1974, Voigt et al. 2007). In particular, pregnant and lactating frugivorous bats of Phyllostomidae subfamily Stenodermatinae have been observed visiting these mineral licks in high numbers. During reproduction, frugivorous bats may 
suffer from severe nutrient stress, because many fruits are low in physiologically relevant minerals. One example is sodium (Na) that is responsible for a wide set of body functions, such as nerve impulses or the homeostatic balance (National Research Council 2005). This nutrient stress may be pronounced for fruit-eating bats living in nutrient-depleted ecosystems, such as the Amazonian lowlands (Terborgh 1992). Therefore, geophagy serving as mineral supplementation for frugivorous bats has been suggested by several authors (Bravo et al. 2008, 2010; Voigt et al. 2007). However, bats in times of high nutritional demand may also benefit from geophagy by buffering toxic plant secondary compounds in their fruit $\operatorname{diet}$ (Voigt et al. 2008). Thus far, it is unclear whether freeranging bats consume water or clay material at mineral licks. If bats only drink water, they most likely supplement their nutrient-depleted fruit diet with essential nutrients dissolved in the water. Alternatively, if bats ingest additionally clay, it is more likely that they detoxify plant secondary compounds in their diet. In this study, we tested the hypotheses that frugivorous bats visit mineral licks to drink water and to ingest clay.

To evaluate whether frugivorous bats drink water or ingest clay or soil-enriched water at mineral licks, we conducted video observations and analysed chemical elements in bat blood and faeces. We predicted that frugivorous bats captured at mineral licks should have an altered blood composition in relation to frugivorous bats captured in the nearby forest. Further, we predicted that soil tracer elements in bat faeces would indicate soil consumption, if frugivorous bats consume soil or soilenriched water at mineral licks.

As we examined the elemental composition of available water sites in the area, we predicted that water sampled at mineral licks should show higher values of physiologically relevant elements than water sampled at nearby sites. Additionally, we compared the nutrient concentration in fruits from Costa Rica and Ecuador, predicting that fruits from rain forests in the Ecuadorian Amazon which grow on ancient nutrient-poor soils would be more depleted in essential nutrients than those of the more recent Costa Rican rain forests growing on nutrient-rich volcanic soils.

\section{METHODS}

\section{Study sites}

We conducted our study between October and December 2008 at the Tiputini Biodiversity Station (TBS, $0^{\circ} 38^{\prime} \mathrm{S}$, $76^{\circ} 8^{\prime} \mathrm{W}$ ), located in a lowland Amazonian primary rain forest, Orellana Province, Ecuador. For video observations and sampling of bats, we chose nine mineral licks and 15 control sites in the forest. Control sites were randomly selected at open locations such as trails or gap openings at the TBS. Additionally we collected and analysed elements in fruits that are known to be consumed by bats.

For comparative purposes, we collected fruit samples in 2009 at La Selva (LS) Biological Station near Puerto Viejo de Sarapiqui in Costa Rica $\left(10^{\circ} 26^{\prime} \mathrm{N}, 85^{\circ} 59^{\prime} \mathrm{W}\right)$. LS served as a control site in our study, because no mineral licks are known to exist in Central America, even though local bat assemblages include many frugivorous bats, sometimes even the same genera or species as at TBS (Rex et al. 2008).

\section{Video observations at mineral licks}

We observed bats at the mineral licks in Ecuador by using a digital video camera (Sony Digital Handycam DCR-H C39E PAL, Sony Europe) with the night-shot function active. For illumination, we used an ECOLINE IR-Illuminator (Security-Center, Germany). At each of the nine licks, we recorded the behaviour of visiting bats from shortly after sunset (c. 18h00) until 20h00-24h00, depending on battery capacity and weather conditions. We performed video observations directly via a handheld camera or as automated observations with a tripod. Focus points of observation were chosen according to one of three criteria: (1) sites were visited by other animals, such as scraping or drinking spots of spider monkey (Ateles belzebuth, É. Geoffroy) or tapir (Tapirus terrestris, Linnaeus); (2) sites with a good overview of the entire mineral lick; and (3) sites with high bat activity based on our netting experience.

\section{Collection of fruit samples}

We collected potential bat fruits, from a total set of 32 ripe fruits (Table 1), in the vicinity of the two biological stations LS $(\mathrm{n}=15)$ and TBS $(\mathrm{n}=17)$. All fruits were cut into pieces and dried at $50{ }^{\circ} \mathrm{C}$ for about $72 \mathrm{~h}$. All dried samples were kept at ambient temperature in closed ZipLock $^{\mathrm{TM}}$-bags until analysis.

\section{Collection of bat blood and faeces}

In 31 nights, we captured bats between $18 \mathrm{~h} 00$ and $21 \mathrm{~h} 00$ at nine mineral licks and 15 control sites by using groundlevel mist nets (length 6-12 m; 70 dernier/2 ply, 36-mm mesh, five shelves; R. Vohwinkel, Velbert, Germany). We identified bats based on their morphology using two field keys (Timm \& LaVal 1998, Tirira 2007). We held all bats individually in cloth bags for approximately $1 \mathrm{~h}$ to collect faeces. We recorded the following data using a standard protocol: species, body mass (accuracy $0.5 \mathrm{~g}$; Pesola spring balance, Baar, Swiss), sex, age (juvenile, subadult, adult), and reproductive status (reproductively active, inactive, lactating, post-lactating) as outlined in Handley et al. (1991) and Kunz et al. (2009). We measured the length of forearm using a vernier caliper (accuracy $0.1 \mathrm{~mm}$; SPI 
Table 1. Fruits consumed by bats and collected at the study sites in Costa Rica (CR; $\mathrm{n}=15)$ and Ecuador $(\mathrm{E} ; \mathrm{n}=17)$. The number of different individuals that have not been identified to the species level but that contributed as separate species to the analyses is given in parentheses after the genus name.

\begin{tabular}{ll}
\hline Species & Origin \\
\hline Cecropia sp. & $\mathrm{CR}$ \\
Cecropia insignis Liebmann & $\mathrm{CR}$ \\
Cecropia obtusifolia Bertoloni & $\mathrm{CR}$ \\
Dipteryx sp. & $\mathrm{CR}$ \\
Ficus americana Aublet & $\mathrm{CR}$ \\
Ficus insipida Willdenow & $\mathrm{CR}$ \\
Ficus sp. & $\mathrm{CR}$ \\
Lycianthes multiflora Bitter & $\mathrm{CR}$ \\
Passiflora sp. & $\mathrm{CR}$ \\
Piper spp. (3) & $\mathrm{CR}$ \\
Sacoglottis sp. & $\mathrm{CR}$ \\
Solanum sp. & $\mathrm{CR}$ \\
Virola sp. & $\mathrm{CR}$ \\
Cecropia spp. (4) & $\mathrm{E}$ \\
Dialium guianense Sandwith & $\mathrm{E}$ \\
Ficus spp. (4) & $\mathrm{E}$ \\
Lecythidaceae sp. & $\mathrm{E}$ \\
Lauraceae & $\mathrm{E}$ \\
Melastomataceae & $\mathrm{E}$ \\
Piper spp. (4) & $\mathrm{E}$ \\
Virola sp. & $\mathrm{E}$ \\
\hline
\end{tabular}

2000 caliper, West Chester, Pennsylvania, USA). Thirtyone faecal samples were stored singly in Eppendorf tubes filled with $70 \%$ ethanol until further analysis (Table 2). We used ethanol blank samples to account for possible impurities or contamination. From each of 68 bats, we took 50-120 $\mu \mathrm{l}$ of blood, depending on body mass of the species by piercing the antebrachial vein (Kunz \& Nagy 1988) using sterile 23-30-gauge needles (Microlance, Becton Dickison S.A., Spain). All blood samples were dried at $50{ }^{\circ} \mathrm{C}$ for approximately $48 \mathrm{~h}$ and kept at ambient temperature in closed Eppendorf tubes until analyses. We released all bats at the site of capture after species identification and processing as noted above.

\section{Collection of water samples}

At TBS we collected 50-ml samples of water from puddles at each of six mineral licks and four control sites, such as rivers, streams and ponds that are potentially accessible for the bats. We sampled unfiltered water from the surface of the puddles in order to evaluate the actual water bats are confronted with at potential drinking sites. This water was stored in a polytetrafluoroethylene (PTFE) vessel mixed with $1 \mathrm{ml}$ of $65 \mathrm{wt}$. \% ultrapure nitric acid for preservation and was kept at ambient temperature until analysis.

\section{Measurement of elemental composition}

For elemental analyses in blood, fruit and faeces samples, we dissolved the samples using a total digestion apparatus
Table 2. Alphabetical list of insectivorous (I) and fruit-eating bats (F) from which faecal and blood samples were collected around Tiputini Biodiversity Station in Ecuador.

\begin{tabular}{lccc}
\hline & \multicolumn{3}{c}{ Sample size } \\
Species & Diet & Faeces & Blood \\
\hline Artibeus lituratus (Olfers, 1818) & F & 1 & 3 \\
Artibeus obscurus (Schinz, 1821) & F & - & 13 \\
Artibeus planirostris (Spix, 1823) & F & 1 & 4 \\
Carollia castanea H. Allen, 1890 & F & - & 1 \\
Carollia perspicillata (Linnaeus, 1758) & F & - & 9 \\
Chiroderma salvini Dobson, 1878 & F & - & 1 \\
Chiroderma trinitatum Goodwin, 1958 & F & 3 & - \\
Chiroderma villosum Peters, 1860 & F & - & 2 \\
Lophostoma silvicolum d'Orbigny, 1836 & I & 2 & - \\
Mesophylla macconnelli Thomas, 1901 & F & 8 & 2 \\
Mimon crenulatum (É. Geoffroy, 1810) & I & 5 & - \\
Phyllostomus elongatus (É. Geoffroy, 1810) & I & 2 & - \\
Platyrrhinus lineatus (É. Geoffroy, 1810) & F & - & 6 \\
Platyrrhinus sp. & F & - & 6 \\
Rhinophylla fischerae Carter, 1966 & F & - & 1 \\
Rhinophylla pumilio Peters, 1865 & F & - & 6 \\
Sturnira lilium (É. Geoffroy, 1810) & F & 1 & 4 \\
Sturnira magna de la Torre, 1966 & F & 4 & 1 \\
Trachops cirrhosus (Spix, 1823) & I & 1 & - \\
Uroderma bilobatum Peters, 1866 & F & 1 & 1 \\
Uroderma magnirostrum Davis, 1968 & F & 1 & 1 \\
Vampyressa sp. & F & - & 2 \\
Vampyressa thyone Thomas, 1909 & F & 2 & 5 \\
\hline
\end{tabular}

(Picotrace, Bovenden, Germany; Ruppert 1987). A series of 32 solid samples was simultaneously digested in PTFE vessels using a mixture of ultrapure fluoric acid $(40 \%)$, perchloric acid $(70 \%)$ and nitric acid $(65 \%)$ at elevated pressure and temperature $\left(170{ }^{\circ} \mathrm{C}\right.$, all acids cleaned by sub-boiling distillation). During evaporation, acid fumes were removed directly from the samples using clean airflow. Residues of evaporation were dissolved in nitric acid and hydrochloric acid and water at $150{ }^{\circ} \mathrm{C}$. After cooling, the clear solutions were transferred into a 10-ml volumetric flask. The homogenized solutions were stored in polyethylene bottles. During the digestion procedure, we assumed minimal risk of contamination, because ultraclean, sub-boiling distilled acids were used, and because the system was closed during the pressure phase and was sheltered during evaporation. Elemental analyses of the digested samples as well as of the water samples were conducted using inductively coupled plasma emission spectrometry (ICP-OES; Optima 3300 DV, Perkin Elmer) and by inductively coupled plasma mass spectrometry (ICP-MS Elan DRC II; Perkin Elmer SCIEX). The elements Na, potassium $(\mathrm{K})$, magnesium $(\mathrm{Mg})$ and iron $(\mathrm{Fe})$ in faeces and blood samples were selected because they are physiologically relevant nutrients in mammals. Concentrations of $\mathrm{Na}, \mathrm{K}, \mathrm{Mg}, \mathrm{Fe}$, calcium (Ca) and phosphorus (P) from fruit and water samples were also analysed. To evaluate whether bats consume clay at mineral licks, we used the elements aluminium $(\mathrm{Al})$, titanium (Ti), yttrium $(\mathrm{Y})$, cerium $(\mathrm{Ce})$, lanthanum (La) 


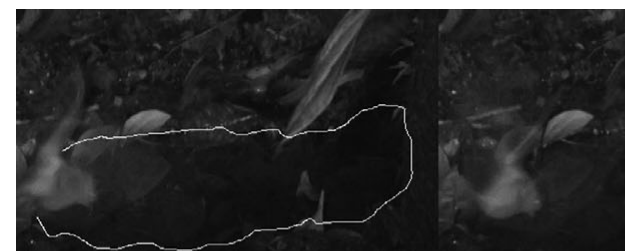

(1) $0 \mathrm{~ms}$

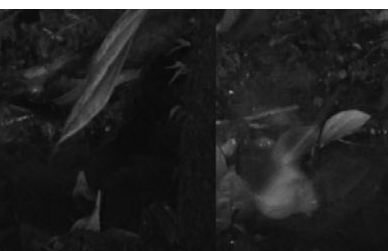

(2) $40 \mathrm{~ms}$

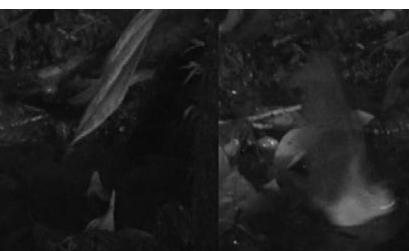

(3) $80 \mathrm{~ms}$
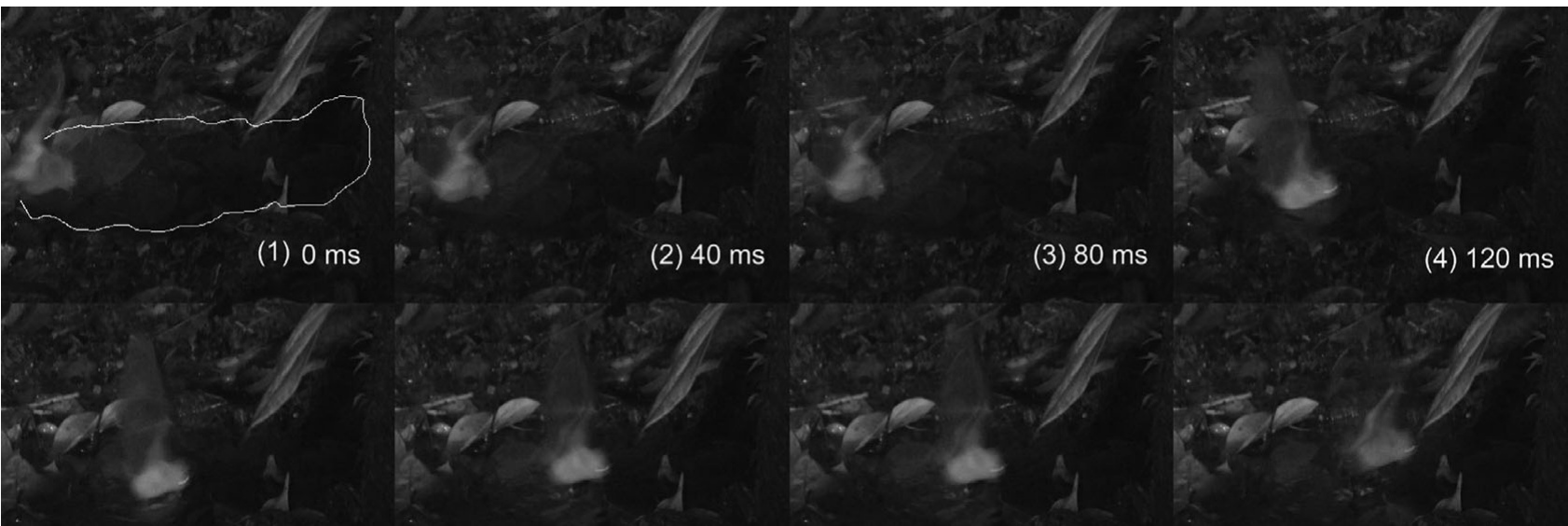

(5) $160 \mathrm{~ms}$
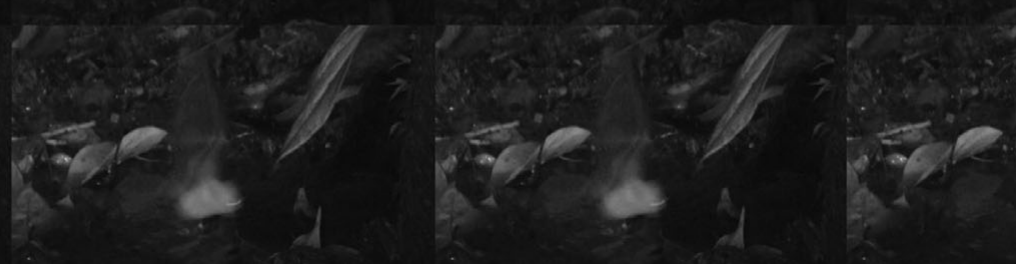

(7) $240 \mathrm{~ms}$

(8) $280 \mathrm{~ms}$

Figure 1. Frames of a video recording within a mineral lick, showing a bat approaching (from left to right) a puddle (in white margins in frame (1)). Frames (2) - (4) show the snout of the bat moving towards the water surface; see online supplementary material for full video.

and neodymium $(\mathrm{Nd})$ in bat faeces as markers to detect soil consumption (Calabrese \& Stanek 1995, Calabrese et al. 1997). These elements are insoluble in water and thus are only sparsely contained in plant products, such as fruits. Bats with a strict fruit diet should not come into contact with these elements when only feeding on fruits that grow on trees or tall shrubs.

\section{Statistics}

We applied a Mann-Whitney U-test to reveal significant differences in the elemental composition between fruit samples from La Selva (Costa Rica) and TBS (Ecuador), as well as for differences in the elemental composition of water samples from mineral licks and control sites.

We transformed blood-sample data using the $\log (x+1)$ function to reduce the effects of numerically dominant categories. Differences in blood composition were tested with samples of two frugivorous-bat groups for both sexes, collected at mineral licks and from open-forest sites, using the statistical software Primer v6 (Primer-236 E 2000 Ltd., Plymouth, UK). We computed the Bray-Curtis similarities for a MDS (multi-dimensional scaling) plot to document evidence of groupings. This plot illustrates the relationship between the two frugivorous groups, by representing the samples as points in two-dimensional space, where the relative dissimilarities of the samples are shown by the relative distances between points. We verified differences in elemental composition of blood by using a two-way crossed analysis of similarity (ANOSIM) permutation test (Clarke \& Warwick 1994).

We applied a Mann-Whitney U-test to reveal significant differences in the soil tracer concentrations between faecal samples of frugivorous bats captured at mineral licks and of co-existing insectivorous bats that have never been recorded to visit mineral licks (Table 2). We used faeces of insectivorous bats that never visit mineral licks as a control group, as we cannot rule out that frugivorous bats captured away from mineral licks might have visited the licks before. This was necessary because the retention time of clay or soil material in the digestive system of an animal is potentially long, as Gilardi et al. (1999) reported for mineral-lick-visiting parrots. We calculated the upper $95 \%$ confidence interval of the median $(95 \% \mathrm{CI})$ of the insectivorous group to establish threshold values that indicated soil consumption by frugivorous species. Since the faecal dataset is not normally distributed we used a non-parametric method to calculate the $95 \% \mathrm{CI}$ of the median according to Olive (http://www.math.siu.edu/olive/ppmedci.pdf). All individuals with values above the upper 95\% CI were considered to have consumed soil. Values within the $95 \%$ CI suggest that animals had not consumed significant amounts of soil recently. We set the level of significance at $5 \%$ and used two-tailed tests.

\section{RESULTS}

\section{Video observations at mineral licks}

During 13 nights (total of $48 \mathrm{~h}$ of recording), we never observed bats feeding directly on clay at scraping spots of other lick-visiting animals. It was difficult to obtain good overview recordings using the automated video observation, due to the size and illumination of the mineral licks. However, by focusing on smaller areas at the same mineral licks using the handheld camera, we detected and observed many bats drinking water from small depressions (Figure 1). 
Table 3. Median mineral nutrient concentrations $\left(\mathrm{mg} \mathrm{g}^{-1}\right.$ of dry matter) of fruits collected from Costa Rica $(\mathrm{n}=18$; CR) and Ecuador $(\mathrm{n}=20$; E); (Mann-Whitney $U$-test, P: $U=64 ; \mathrm{P}=0.016 ; \mathrm{K}: U=72 ; \mathrm{P}=0.037$; Na: $U=56 ; \mathrm{P}=0.007 ;{ }^{*} \mathrm{P}<0.05$ ). The mineral concentration of Piper sp. infructescences was used to calculate the daily mineral shortfall of Carollia bats when consuming exclusively Piper infructescences. We estimated a daily fruit consumption of $\sim 24 \mathrm{~g}$ for C. brevicauda and assumed that $70 \%$ of consumed element amounts were taken up by the bat ( $70 \%$ taken up). Additionally, we calculated the difference in element content $(\Delta)$ between diets of Piper spp. fruits in Costa Rica and Ecuador as well as the average element concentration $\left(\mu \mathrm{g} \mathrm{g}^{-1}\right)$ of lick water (ML; $\mathrm{n}=6$ mineral licks) and control water sites ( $\mathrm{CW} ; \mathrm{n}=4$ control sites) in Ecuador (Mann-Whitney $U$-test, $\mathrm{n}=10$, Na: $U=64 ; \mathrm{P}<0.001 ; \mathrm{Mg}: U=32 ; \mathrm{P}<0.001 ; \mathrm{K}: U=96 ; \mathrm{P}=0.007$; Ca: $\left.U=32 ; \mathrm{P}<0.001 ;{ }^{*} \mathrm{P}<0.05\right)$.

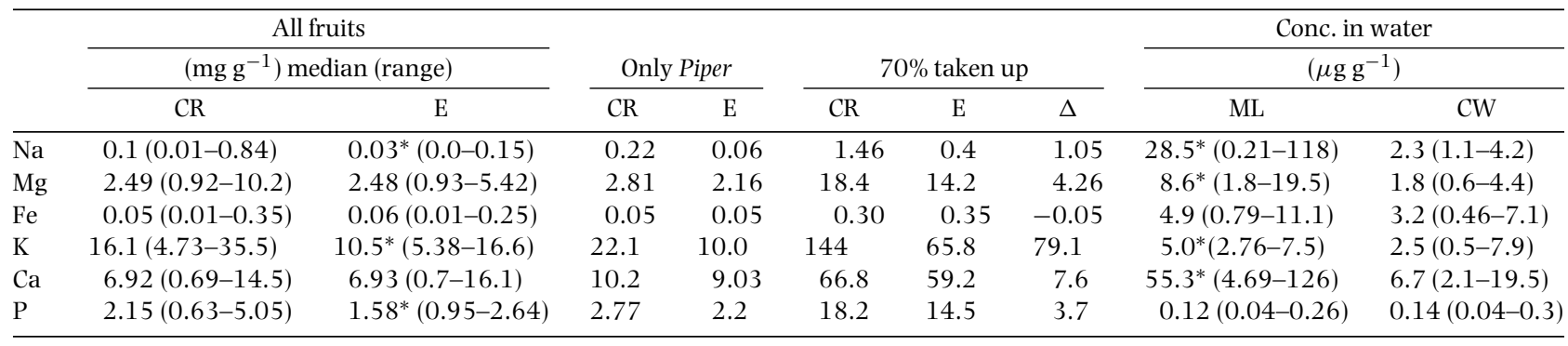

\section{Elemental composition of fruits}

Fruits from Ecuador showed significantly lower concentrations of $\mathrm{P}, \mathrm{K}$ and $\mathrm{Na}$ than fruits from Costa Rica (Mann-Whitney $U$-test, $\mathrm{n}=32$; phosphorus: $U=64$; $\mathrm{P}=0.016$; potassium: $U=72 ; \mathrm{P}=0.037$; sodium: $U=$ $56 ; \mathrm{P}=0.007$; Table 3).

\section{Elemental blood composition}

The two-way crossed ANOSIM permutation test revealed a significant global $\mathrm{R}$ value of $0.188(\mathrm{n}=68 ; \mathrm{P}=0.025)$ for the two locations, suggesting significant differences in elemental composition of blood between the two groups. Of the 9999 permutations in our model, only 245 were equal to or greater than the global $\mathrm{R}$, which indicates a high within-group similarity. The tests for the differences between sexes did not reveal a significant difference (Global $\mathrm{R}=0.032 ; \mathrm{P}=0.246$ ). Of the 9999 permutations, 2463 were equal to or greater than the global R. The Bray-Curtis dissimilarity matrix among all pairs of objects was used to construct a MDS plot for the two locations (Figure 2), which suggests groupings according to capture site (two-dimensional stress level $=0.19$ ).

\section{Elemental composition of water}

Water collected from puddles at mineral licks showed significantly higher concentrations of $\mathrm{Na}, \mathrm{Mg}, \mathrm{K}$ and $\mathrm{Ca}$ when compared with the concentrations of the control sites (Mann-Whitney $U$-test, $\mathrm{n}=10$, sodium: $U=64$; $\mathrm{P}<0.001$; magnesium: $U=32 ; \mathrm{P}<0.001$; potassium: $U=96 ; \mathrm{P}=0.007$; calcium: $U=32 ; \mathrm{P}<0.001$; Table 3 ). The concentrations of $\mathrm{Fe}$ and $\mathrm{P}$ did not differ significantly (Mann-Whitney $U$-test, $\mathrm{n}=10$, iron: $U=132 ; \mathrm{P}=0.1$; phosphorus: $U=93 ; \mathrm{P}=0.404$; Table 3 ).

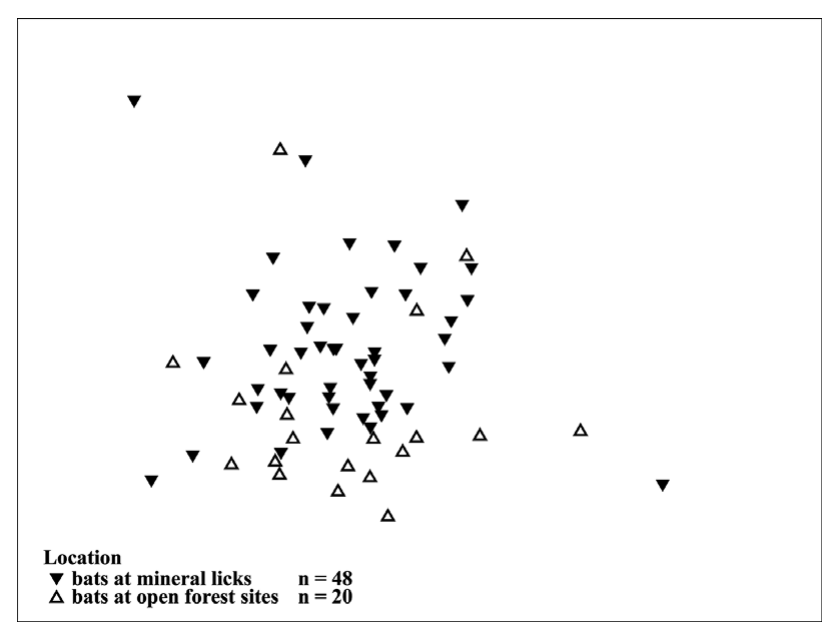

Figure 2. Two-dimensional MDS plots of soil tracer elements in blood of bats captured at mineral licks (filled triangles, $\mathrm{n}=48$ ) and nearby forest sites (open triangles, $\mathrm{n}=20$ ). The similarity matrix was computed using the Bray-Curtis Similarity Index (2D stress 0.19). The more similar the elemental compositions of bats, the closer the symbols appear on the plot.

\section{Soil markers in faeces}

The calculated threshold (upper 95\% CI of the median of insectivorous group) for soil consumption revealed that $19-48 \%$ of the frugivorous species exhibited soil-tracer concentrations in faeces that were higher than those of insectivorous species (Figure 3). Faeces of frugivorous species that visit mineral licks were significantly more enriched in the soil tracer aluminium than the droppings of insectivorous bats that do not visit mineral licks (MannWhitney $U$-test; $\mathrm{n}=31, U=40 ; \mathrm{P}=0.032$ ).

\section{DISCUSSION}

We tested the hypothesis that frugivorous bats ingest water for nutrient supplementation or soil material 

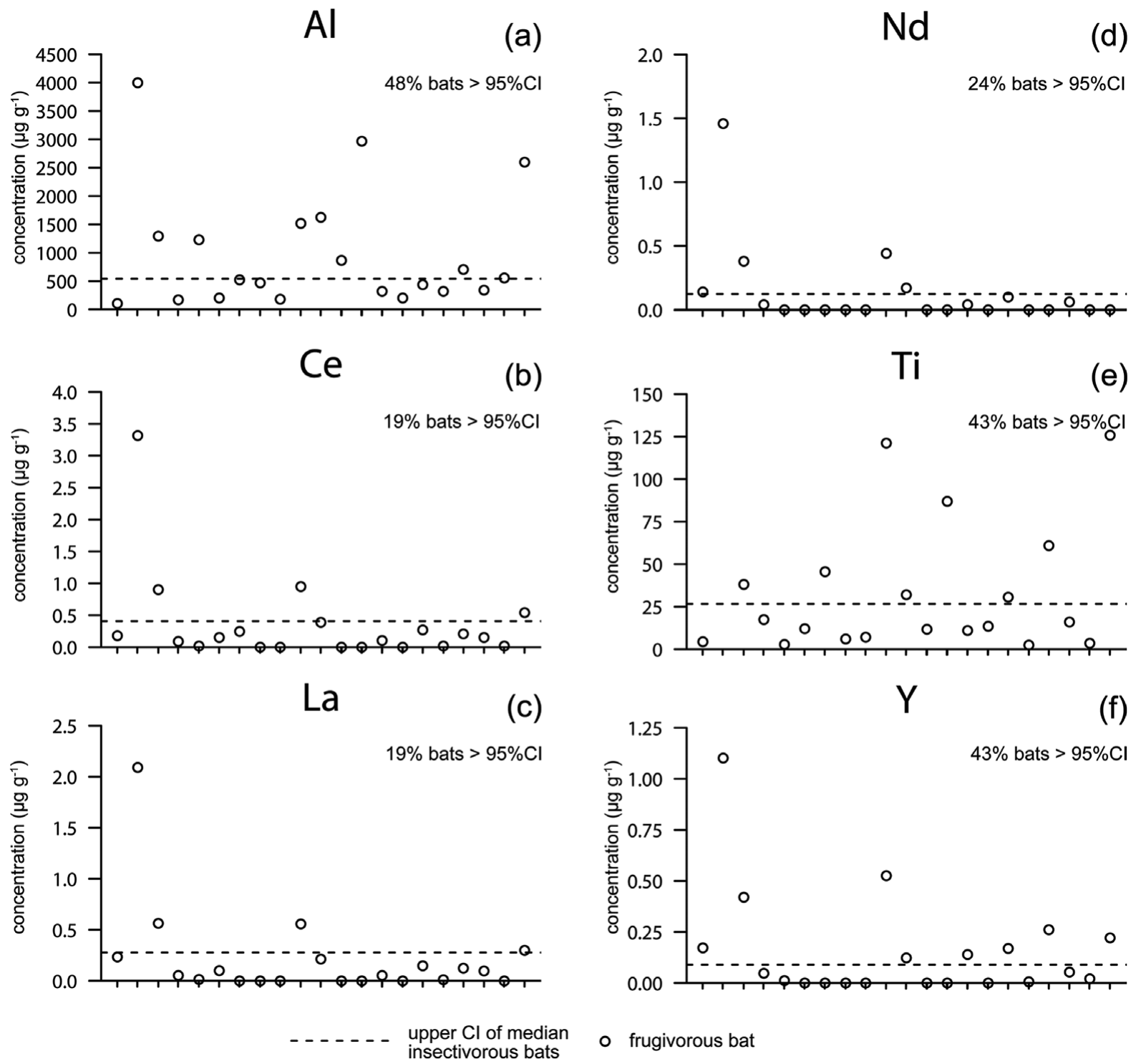

Figure 3. Soil tracer concentrations ( $\mu \mathrm{g} \mathrm{g}^{-1}$ of dry matter) of the soil tracer elements $\mathrm{Al}=$ aluminium (a), $\mathrm{Ce}=$ cerium (b), La $=$ lanthanum (c), $\mathrm{Nd}=$ neodymium (d), $\mathrm{Ti}=$ titanium (e), and $\mathrm{Y}=$ yttrium (f), in droppings of frugivorous bats (every tick on the $\mathrm{x}$-axis is a sample, $\mathrm{n}=21$ ) captured at mineral licks in eastern Ecuador. The upper $95 \%$ confidence interval of the median $(95 \% \mathrm{CI})$ of soil tracer concentrations in the faeces of insectivorous bats $(\mathrm{n}=10)$ served as a baseline soil tracer concentration for bats not consuming soil. We considered frugivorous bats as soil consumers, when tracer concentrations in their faecal material were above the upper $95 \% \mathrm{CI}$ of soil tracer concentrations in the faeces of insectivorous bats (see given percentages).

for detoxification at mineral licks of the Amazon rain forest. Similar to previous studies, we captured mostly reproductively active female frugivorous species visiting mineral licks (Bravo et al. 2008, 2010; Tuttle 1974, Voigt et al. 2007, 2008). Although, we were not able to document large numbers of drinking bats with our automated camera setup, our video observations with hand-held cameras demonstrate unambiguously that bats drank water at mineral licks in the lowland Ecuadorian Amazon. We suggest that this water uptake is most likely unrelated to the daily water requirements, because frugivorous species usually consume large amounts of water when ingesting fruits (Morrison 1980, Ruby et al. 2000). The high water content of fruits is presumably sufficient for lactating bats when facing elevated water demands during milk production. Instead, frugivorous bats are probably attracted to the water-filled depressions at mineral licks, because the water is more enriched in nutrients such as sodium than water from local creeks, ponds or rivers. In support of the nutrient supplementation hypothesis, we found that the composition of physiologically relevant 
elements ( $\mathrm{Na}, \mathrm{Mg}, \mathrm{K}$ and $\mathrm{Fe}$ ) differed between blood collected from frugivorous bats at mineral licks and blood collected from bats at open-forest sites. Still, one has to be careful interpreting the results of the blood elemental comparison. Because bats are highly mobile, our study design allows that individuals captured far away from mineral licks may have visited mineral licks as well. Further, the calculated ANOSIM might be sensitive to the varying sample sizes of species. Not controlling for this variation might compromise our data by pseudoreplication and bias the results towards those species with large sample size, for example Artibeus obscurus. However, none of the species with large sample sizes showed extreme values and therefore, we consider our analysis as robust against such biases. Nevertheless, we have been able to document significant differences in the elemental blood composition between bats from the two locations. Based on these differences, we infer that traces of the nutrient-enriched water consumed by bats at mineral licks can be found in their blood samples, even though elemental composition of blood is probably regulated within narrow ranges. This finding is interesting given that extreme deviations of elemental concentrations from the range of physiological acceptable values may be detrimental or even fatal to mammals. Thus, our finding may provide further support for the hypothesis that bats take up nutrients at mineral licks by drinking water from small puddles. A key question related to this is whether fruits from plants growing in the Amazonian ecosystem provide sufficient quantities of essential mineral nutrients to meet the daily requirements of frugivorous bats during reproduction. Bravo et al. (2010) reported that figs in Peru include less sodium than fruits of other tropical regions. Other studies in Peru showed that parrots with diets extremely low in sodium often supplement their diets by eating soils with high concentrations of sodium, most likely to meet their daily nutrient demands (Brightsmith \& Muñoz-Najar 2004, Gilardi et al. 1999). In the present study, we showed that nutrient concentrations of fruits collected from Ecuadorian rain forests had less sodium, potassium and phosphorus than fruits from Costa Rican rain forests. Although we may introduce a bias with dry-weight comparisons or a limited sample size, our findings are in accordance with the data of the Peruvian studies that suggest that the western Amazon region is generally depleted in mineral nutrients. This can be attributed to the unique geographical features of the western lowland Amazon. This region is essentially beyond coastal climate and thus marine input of sodium, because of its isolation from the Pacific Ocean by the Andes to the west, and the Atlantic Ocean to the east (Kaspari et al. 2008). Moreover, the soils of the Amazonian rain forest are ancient and have degraded and leached over millions of years (Terborgh 1992). A recent study by
Dudley et al. (2012) proposed a cross-taxonomic need for sodium especially in the Western Amazon region, where mineral licks are used to minimize the nutritional deficit. Thus, low concentrations of nutrients in plants and their associated fruits may be caused by the nutrient depletion of Amazonian soils (Jordan \& Herrera 1981, Stark 1970). Mineral licks and mineral supplementation may become superfluous in areas with overall higher levels of mineral nutrients in their soils, such as in Costa Rica.

Based on nutrient data from the infructescences of Piper collected in Ecuador and Costa Rica, and the measured rates of water flux in Carollia brevicauda, a frugivorous bat species and Piper specialist (Voigt et al. 2006), we estimated the nutritional deficit in this species when consuming only Ecuadorian fruits. For the daily water flux of $30 \mathrm{ml} \mathrm{d}^{-1}$ for C. brevicauda (Voigt et al. 2006), we assumed that about $20 \%$ of this water flux originates from the oxidation of fat as metabolic water. Thus, C. brevicauda must consume approximately $24 \mathrm{ml} \mathrm{d}^{-1}$ of water from fruits to maintain its daily water balance. Given that fruits are comprised of about $70 \%$ water, we estimated that this fruit-eating species handles approximately $31 \mathrm{~g}$ of fruits each day. As a conservative approach, we assumed that a bat takes up about $70 \%$ of the nutrients of the consumed fruits. Thus, C. brevicauda in Ecuador would be expected to consume about $1 \mathrm{mg}$ sodium, $8 \mathrm{mg}$ calcium and $4 \mathrm{mg}$ magnesium less than a respective Costa Rican individual on a daily basis. For sodium the daily minimum requirements of small mammals in their most demanding life periods have been reported to be $600 \mathrm{ppm}$ on a dry matter basis (Dempsey 2004). The estimated sodium values for Ecuadorian C. brevicauda when consuming exclusively Piper infructescences lay below these minimum requirements. However, our nutrient analysis of water from mineral licks suggests that a daily consumption of $1-2 \mathrm{ml}$ of minerallick water may be sufficient to compensate for this deficit depending on the bioavailability of the dissolved nutrients.

A notable problem in most studies that have measured the composition of tropical fruits is that they focused on total availability of nutrients in fruits rather than on the bioavailability of mineral elements. Fruits that contain large amounts of secondary compounds such as phytate or oxalate can limit the bioavailability of nutrients (Kamchan et al. 2004). One such example can be observed in figs, a food item largely preferred by the genus Artibeus. While figs are known to be rich in total calcium (Wendeln et al. 2000), they often contain high levels of oxalate that not only bind the calcium in the fruit (Kamchan et al. 2004), but may also reduce the amount of calcium available to the animal when it is consumed. Thus, many fig-eating bats may actually lack essential nutrients in their diet. 
In addition to a higher demand for nutrients, reproductively active bats also have higher energy demands (Korine et al. 2004, Racey \& Speakman 1987, Voigt 2003). Thus, an increase in fruit consumption in response to these demands should lead to an increase in secondary metabolites absorbed. Many of these compounds negatively affect their consumers, because they can be carcinogenic, teratogenic, toxic, or they may simply bind to elements as do phytate or oxalate (Heiser 1969, Kamchan et al. 2004).

The elemental analysis of bat droppings in our study revealed higher concentrations of soil tracers in faeces collected from frugivorous species compared with our calculated threshold for soil consumption $(95 \%$ CI of the median). As this threshold is based on insectivorous bats that were never observed at mineral licks, higher concentrations of soil tracers provide clear evidence for geophagy in frugivorous bats of the lowland Amazonian rain forest.

The soil tracer aluminium is a major structural component of clay minerals such as kaolinites or smectites (Mahaney \& Krishnamani 2003). A higher enrichment of this element in faeces strongly suggests that fruiteating bats consume clay minerals or other soil fractions while they are visiting water puddles at mineral licks. In a wide range of studies on birds and mammals, the consumption of clay minerals was linked to detoxification of plant secondary compounds. Brightsmith et al. (2008) and Gilardi et al. (1999) showed that clay minerals such as kaolinite buffer remarkable amounts of the toxin quinine, which is similar in structure to other compounds that occur in the diets of frugivorous parrots. Given these observations, it seems quite likely that bats could also benefit from the buffering and thus detoxifying effects of consumed clay minerals.

Our findings provide direct evidence that frugivorous bats obtain both essential mineral nutrients and soil material at mineral licks by drinking water from these sites. Two reasons may be causal for the drinking behaviour of female frugivorous bats during reproduction, apart from a demand for water: (1) female frugivorous bats may require more essential elements during reproduction than their diet of fruit can supply, and (2) possible exposure to higher levels of plant secondary metabolites may require the use of clay minerals as a detoxifying buffer. Although our correlative study design may allow other explanations, we suggest that in a mineral-depleted area, such as Western Amazonia, the drinking behaviour of frugivorous bats at mineral licks serves a dual function, namely nutrient supplementation and detoxification of plant secondary compounds in their diet. Our findings may help as a basis for future captive studies to quantify mineral and toxic levels of diets and to disclose their physiological consequences for bats in the wild such as mineral deficiency or intoxication.

\section{SUPPLEMENTARY MATERIAL}

For supplementary material for this article, please visit http://dx.doi.org/10.1017/S0266467412000740.

\section{ACKNOWLEDGEMENTS}

We wish to thank the administrative staff at the Tiputini Biodiversity Field Station and the La Selva Biological Station, as well as the governmental authorities of Ecuador and Costa Rica for granting permission to work. We also thank Lena John, Jaime Guerra for field assistance and Ursula Grunewald and Irina Ottenbacher who kindly did the sample preparation and the digestion for the geochemical analysis. All protocols were approved by the Animal Care and Use Committee from the Leibniz Institute for Zoo and Wildlife Research and from Boston University. This study was supported by a grant from the German National Council to CCV (Vo 890/15), and from Boston University's Center for Ecology and Conservation Biology.

\section{LITERATURE CITED}

ABRAHAMS, P. W. \& PARSONS, J. A. 1996. Geophagy in the tropics: a literature review. The Geographical Journal 162:63-72.

BLAKE, J. G., GUERRA, J., MOSQUERA, D., TORRES, R., LOISELLE, B. A. \& ROMO, D. 2010. Use of mineral licks by white-bellied spider monkeys (Ateles belzebuth) and red howler monkeys (Alouatta seniculus) in eastern Ecuador. International Journal of Primatology 31:471-483.

BRAVO, A., HARMS, K. E., STEVENS, R. D. \& EMMONS, L. H. 2008. Collpas: activity hotspots for frugivorous bats (Phyllostomidae) in the Peruvian Amazon. Biotropica 40:203-210.

BRAVO, A., HARMS, K. E. \& EMMONS, L. H. 2010. Puddles created by geophagous mammals are potential mineral sources for frugivorous bats (Stenodermatinae) in the Peruvian Amazon. Journal of Tropical Ecology 26:173-184.

BRIGHTSMITH, D. J. \& MUÑOZ-NAJAR, R. A. 2004. Avian geophagy and soil characteristics in southeastern Peru. Biotropica 36:534543.

BRIGHTSMITH, D. J., TAYLOR, J. \& PHILLIPS, T. D. 2008. The roles of soil characteristics and toxin adsorption in avian geophagy. Biotropica 40:766-774.

CALABRESE, E. J. \& STANEK, E. J. 1995. A dog's tale - soil ingestion by a canine. Ecotoxicology and Environmental Safety 32:93-95.

CALABRESE, E. J., STANEK, E. J., PEKOW, P. \& BARNES, R. M. 1997. Soil ingestion estimates for children residing on a superfund site. Ecotoxicology and Environmental Safety 36:258-268.

CLARKE, K. R. \& WARWICK, R. M. 1994. Change in marine communities: an approach to statistical analysis and interpretation. Natural Environment Research Council, London. 144 pp.

DEMPSEY, J. L. 2004. Fruit bats: nutrition and dietary husbandry. Nutrition Advisory Group Handbook 14:1-17. 
DIAMOND, J. M. 1999. Evolutionary biology: dirty eating for healthy living. Nature 400:120-121.

DIAMOND, J., BISHOP, K. D. \& GILARDI, J. D. 1999. Geophagy in New Guinea birds. Ibis 141:181-193.

DUDLEY, R., KASPARI, M. \& YANOVIAK, S. P. 2012. Lust for salt in the Western Amazon. Biotropica 44:6-9.

EMMONS, L. H. \& STARK, N. M. 1979. Elemental composition of a natural mineral lick in Amazonia. Biotropica 11:311313.

GILARDI, J. D., DUfFeY, S. S., MUNN, C. A. \& TELL, L. A. 1999. Biochemical functions of geophagy in parrots: detoxification of dietary toxins and cytoprotective effects. Journal of Chemical Ecology 25:897-922.

HANDLEY, C. O., WILSON, D. E. \& GARDNER, A. L. 1991. Demography and natural history of the common fruit bat, Artibeus jamaicensis, on Barro Colorado Island, Panama. Smithsonian Institution Press, Baltimore.

HEISER, C. B. 1969. The wonderberry. Pp. 62-105 in Nightshades: the paradoxical plants. W. H. Freeman \& Co., San Francisco.

HOLDØ, R. M., DUDLEY, J. P., MCDOWELL, L. R. \& TOMASI, T. E. 2002. Geophagy in the African elephant in relation to availability of dietary sodium. Journal of Mammalogy 83:652-664.

JORDAN, C. F. \& HERRERA, R. 1981. Tropical rain forests: are nutrients really critical? American Naturalist 117:167-180.

KAMCHAN, A., PUWASTIEN, P., SIRICHAKWAL, P. P. \& KONGKACHUICHAI, R. 2004. In vitro calcium bioavailability of vegetables, legumes and seeds. Journal of Food Composition and Analysis 17:311-320.

KASPARI, M., YANOVIAK, S. P. \& DUDLEY, R. 2008. On the biogeography of salt limitation: a study of ant communities. Proceedings of the National Academy of Sciences USA 105:1784817851.

KLAUS, G. \& SCHMID, D. B. 1998. Geophagy at natural licks and mammal ecology: a review. Mammalia 62:481-497.

KORINE, C., SPEAKMAN, J. \& ARAD, Z. 2004. Reproductive energetics of captive and free-ranging Egyptian fruit bats (Rousettus aegyptiacus). Ecology 85:220-230.

KREULEN, D. 1985. Lick use by large herbivores: a review of benefits and banes of soil consumption. Mammal Review 15:107123.

KRISHNAMANI, R. \& MAHANEY, W. C. 2000. Geophagy among primates: adaptive significance and ecological consequences. Animal Behaviour 59:899-915.

KUNZ, T. H. \& NAGY, K. A. 1988. Methods of energy budget analysis. Pp. 277-302 in Kunz, T. H. (ed.) Ecological and behavioral methods for the study of bats. Smithsonian Institution Press, Washington, DC.

KUNZ, T. H., ADAMS, R. A. \& HOOD, W. R. 2009. Methods for assessing postnatal growth and development of bats. Pp. 273-324 in Kunz, T. H. \& Parson, S. (eds.) Ecological and behavioral methods for the study of bats. (Second edition). Johns Hopkins University Press, Baltimore.
MAHANEY, W. C. \& KRISHNAMANI, R. 2003. Understanding geophagy in animals: standard procedures for sampling soils. Journal of Chemical Ecology 29:1503-1523.

MONTENEGRO, O. L. 2004. Natural licks as keystone resources for wildlife and people in Amazonia. Ph.D. dissertation, University of Florida, Gainesville.

MORRISON, D. W. 1980. Efficiency of food utilization by fruit bats. Oecologia 45:270-273.

NATIONAL RESEARCH COUNCIL. 2005. Mineral tolerance of animals. National Academies Press, Washington, DC. 510 pp.

RACEY, P. A. \& SPEAKMAN, J. R. 1987. The energy costs of pregnancy and lactation in heterothermic bats. Symposium of the Zoological Society of London 57:107-125.

REX, K., KELM, D. H., WIESNER, K., MATT, F., KUNZ, T. H. \& VOIGT, C. C. 2008. Structure of three Neotropical bat assemblages. Biological Journal of the Linnean Society 94:617-629.

RUBY, J., NATHAN, P. T., BALASINGH, J. \& KUNZ, T. H. 2000. Chemical composition of leaves and fruits eaten by the short-nosed fruit bat, Cynopterus sphinx (Megachiroptera). Journal of Chemical Ecology 26:2825-2841.

RUPPERT, H. 1987. Bestimmung von Schwermetallen im Boden sowie die ihr Verhalten beeinflussenden Bodeneigenschaften. Beilage zum GLAFachbericht 2, Munich. 11 pp.

STARK, N. 1970. The nutrient content of plant and soils from Brazil and Surinam. Biotropica 2:51-60.

TERBORGH, J. 1992. Diversity and the tropical rain forest. Scientific American Library, New York. 242 pp.

TIMM, R. M. \& LAVAL, R. K. 1998. A field key to the bats of Costa Rica. Occasional Publication Series, Center of Latin American Studies, University of Kansas 22:1-30.

TIRIRA, S. D. 2007. Guía de Campo de los Mamíferos del Ecuador. Quito. $576 \mathrm{pp}$.

TUTTLE, M. D. 1974. Unusual drinking behavior of some stenodermine bats. Mammalia 38:141-144.

VOIGT, C. C. 2003. Reproductive energetics of the nectar-feeding bat Glossophaga soricina (Phyllostomidae). Journal of Comparative Physiology B 173:79-85.

VOIGT, C. C., KELM, D. H. \& VISSER, G. H. 2006. Field metabolic rates of phytophagous bats: do pollination strategies of plants make a life of nectar-feeders spin faster? Journal of Comparative Physiology B 176:213-222.

VOIGT, C. C., DECHMANN, D. K. N., BENDER, J., RINEHART, B. J., MICHENER, R. H. \& KUNZ, T. H. 2007. Mineral licks attract neotropical seed-dispersing bats. Research Letters of Ecology 2007: Article ID 34212.

VOIGT, C. C., CAPPS, K. A., DECHMANN, D. K. N., MICHENER, R. H. \& KUNZ, T. H. 2008. Nutrition or detoxification: why bats visit mineral licks of the Amazonian rainforest. PLoS ONE 3: e2011.

WENDELN, M. C., RUNKLE, J. R. \& KALKO, E. K. V. 2000. Nutritional values of 14 fig species and bat feeding preferences in Panama. Biotropica 32:489-501. 
Resumen: En la Amazonia Central, los mamíferos grandes construyen charcos de agua durante el consumo del suelo. Estos saladeros son frecuentemente visitados por murciélagos frugívoros por dos posibles razones: suplementar su dieta baja en minerales por medio de beber agua con alto contenido de sales o amortiguar compuestos secundarios provenientes de plantas. Hemos analizado frutos consumidos por murciélagos en Ecuador y observamos una reducción en el contenido de minerales $(\mathrm{Na}, \mathrm{K}, \mathrm{P}$ ) en comparación con frutos similares colectados en Costa Rica, donde no existen saladeros $(\mathrm{n}=32)$. Los análisis de agua de seis saladeros en Ecuador revelaron un mayor contenido de minerales con relevancia fisiológica ( $\mathrm{Na}, \mathrm{K}, \mathrm{Mg}$, Ca) a cuatro muestras de puntos de control de ríos y afluentes. Con el uso de cámaras infrarrojas grabamos murciélagos tomando agua en saladeros. Determinamos si los murciélagos ingieren minerales al tomar agua rica en nutrientes en los saladeros comparando el contenido de minerales con relevancia fisiológica (Na, $\mathrm{K}, \mathrm{Mg}, \mathrm{Fe}$ ) en la sangre de 68 murciélagos que visitan los saladeros con murciélagos capturados en sitios de control. La sangre de murciélagos frugívoros capturados en los saladeros difiere en su composición de minerales de la de murciélagos capturados en otros sitios. También examinamos si los murciélagos consumían arcilla buscando trazas de suelo en 31 muestras de heces. Dichas trazas son insolubles en agua y, por lo tanto, no incluidas en una dieta frugívora. Los murciélagos frugívoros que visitan los saladeros mostraron una mayor concentración de trazas de suelo en las heces que murciélagos insectívoros que nunca los visitan. Nuestros resultados proveen evidencia que los murciélagos frugívoros ingieren nutrientes minerales solubles y arcilla insoluble al consumir agua enriquecida con arcilla en los saladeros. Esto apoya la hipótesis que los murciélagos frugívoros de la Amazonia occidental obtienen un doble beneficio al visitar dichos saladeros. 